\title{
Epidemiological Study of Hypertensive Patients in Relation to Clinical Phenotyping as Per Unani Concept
}

\author{
Thulasamma $^{1}$, Alokananda Chakraborty ${ }^{2}$, Kaiser Jamil ${ }^{3}$ \\ ${ }^{1,2}$ Central Research Institute of Unani Medicine, Hyderabad, ESI x Road, Hyderabad, Telangana, India -500038 \\ ${ }^{3}$ Bhagwan Mahavir Medical Research Centre, 10-1-1, Mahavir Marg, Hyderabad-500004, Telangana, India
}

\begin{abstract}
Background: A century old Unani system has been existing in the world for the cure of human illnesses. The science behind this system has been poorly understood. Modern technology has now been starting to infiltrate into this system only recently. Hence keeping the Unani principles in mind we have attempted to present the epidemiological parameters of hypertensive patients and their segregation for treatment modalities. Methods: Hypertensive patients defined by high blood pressure diagnosis were selected for this study along with equal number of controls. The Unani system of Medicine recognizes mainly four categories of classification of patients such as Damvi (Sanguine), Balghami (Phlegmatic), Safravi (Bilious) and Saudavi (Melancholic). The Unani clinicians selected thehypertensive cases which had the dominant phenotype of Damvi category. A specially designed case record form as per the Unani classical text was designed for assessment of humours and the information obtained were recorded from healthy volunteers as well as patients. Results: Hypertension (HT) is measure by Increase in blood pressure, and scientific literature indicates that nitric oxide (NO) plays a major role in regulating blood pressure and glucose levels, hence we have genotyped the eNOS gene polymorphism (by PCRRFLP) and we found heterozygous genotype as dominant compared to controls. We also determined the biochemical parameters like plasma glucose levels (fasting and postprandial), total cholesterol, triglycerides, liver function tests and renal function tests were also analyzed by using an Erba auto analyzer and found increase in the levels of these parameters. Conclusion: Based on the epidemiological parameters the difference between the genotypes in the heterozygous category of the HT patients and controls was $21 \%$ and $13 \%$ respectively, which is a highly significant difference. This is the first step in categorizing the Damvi (Sanguine) patients based on Unani principles, and these were selected for undergoing Unani treatment, which is being communicated separately.
\end{abstract}

Keywords: eNOS, Genotyping, Damvi (Sanguine), Hypertension, Unani principles

\section{Introduction}

GWAS- study reveals that most genetic variation is due to inter-individual differences at genetic loci within populations. The enormous heterogeneity in expression and sequence variation of genes coupled with genetic network interactions and environmental factors contributes to phenotypic diversity in health and disease. In Unani system of medicine predisposition to a disease as well as selection of a preventive and curative regime is primarily based on phenotypic assessment of a person which includes one's body constitution termed "Mizaj". Mizaj means "temperament" which is a consequence of relative proportion of four entities: (i) dam (blood), (ii) balgham (phlegm), (iii) safra (bile) and (iv) sauda (melanin) which is determined by extracting information from the individual themselves through a questionnaire, and also by physical examination of the individual and further extrinsic factors also play a role in it ${ }^{(1,2,3)}$.

Temperament is responsible for the maintenance of homeostasis of the body as well as of all function and coordination in the body as per the Unani philosophy ${ }^{(4)}$. Distinct properties and functions have been attributed to some of these parameters like signaling, movement, metabolism, cognition, thermoregulation etc. as these have been defined in Unani classical texts ${ }^{(5,6,7)}$. Unani philosophy describes that this clinical phenotypic diversity is the resultant effect of four different relative proportions of dam, balgham, safra and sauda. The above philosophy forms the basis of Unani system of Medicine in health, disease, diagnosis and treatment and they are referred to as Damvi (Sanguine), Balghami (Phlegmatic),Safravi (Bilious) and Saudavi (Melancholic) Keeping the Unani principles in focus we have aimed to understand a silent disease Hypertension (HT) which is a common disorder among our population, which is never recognized at early stages ${ }^{(8,9,10)}$.

Generally hypertension is defined as a systolic blood pressure of $140 \mathrm{mmHG}$ or more and a diastolic blood pressure of $90 \mathrm{mmHg}$ or more, this has a high risk of cardiovascular failure leading to mortality and morbidity. HT patients can be frequently associated with other diseases such as diabetes or other renal disorders. The treatment for this disease if recognized or diagnosed is a drug Methyldopa which reduces blood pressure- a dosage of 750 mg daily. However there are concerns about its adverse side effects. Due to the adverse side effects of this drug and other drugs, people and turning toward alternate medicine, hence the objective of our study was to identify the temperament of both Hypertensive and control group as the philosophy of Unani system of medicine which may be designated as clinical phenotyping. We also aim to study the genetic causes of HT. Later on, the effect of Unani formulations against patients suffering from HT will be evaluated.

Evidence suggests that nitric oxide (NO) plays a major role in regulating blood pressure and glucose levels, and thus impaired NO bioactivity forms an important component of hypertension and diabetes. The physiological importance of NO in the regulation of blood pressure is evidenced by the fact that pharmacological inhibition of NO synthesis leads to 


\section{International Journal of Science and Research (IJSR) \\ ISSN (Online): 2319-7064 \\ Index Copernicus Value (2013): 6.14 | Impact Factor (2014): 5.611}

severe hypertension, vascular injury, and glomerulosclerosis in experimental animals. ${ }^{[11]}$ Among humans younger than 50 years of age, hypertension occurs 3.8 times more often in those having two or more first-degree relatives who developed high blood pressure before age $55^{(12) \text {. }}$

Endothelium, which is an inert single-cell lining covering the internal surface of blood vessels, plays a crucial role in vascular homeostasis by regulating vascular tone and structure. Nitric oxide is the most pivotal molecule secreted by endothelium and thus is a major mediator of endothelial function ${ }^{(13)}$. The production of NO is catalyzed by family of enzymes called as nitric oxide synthases (NOS), which convert the amino acid $\mathrm{L}$-arginine to L-citrulline and NO [14]. Three isoforms of NOS, specific to different organ systems, exist. Apart from playing an important role in vasodilation, NO is also critically involved in the regulation of other protective properties of the healthy endothelium by playing an important role in a wide range of physiological processes like platelet and leukocyte aggregation, [15] leukocyte adhesion, [16] cell proliferation and vasoconstriction $^{[17,18]}$.

Endothelial dysfunction is associated with disruption of vascular homeostasis leading to proinflammatory and prothrombotic phenotype of the endothelium; thus, it may play a pivotal role in the development and progression of secondary complications both in diabetes and hypertension.

\section{Cytogenetic Location of eNOS gene: 7q36}

Molecular Location on chromosome 7: base pairs $150,991,056$ to $151,014,599$

(Homo sapiens Annotation Release 107, GRCh38.p2)

$(\mathrm{NCBI} \rightrightarrows)$

\section{Role of NO in HT}

With a genetic contribution of from $25 \%$ to $60 \%$, human essential hypertension has a genetic basis. NO synthesis by the vascular endothelium is important for the regulation of vasodilator tone and the control of blood pressure in humans (19). A recent study using mice with disrupted eNOS gene revealed that eNOS function is required for vascular and hemodynamic responses to acetylcholine and that the disruption of the eNOS gene leads to hypertension ${ }^{(20)}$. Moreover, recent reports demonstrate that whole-body NO

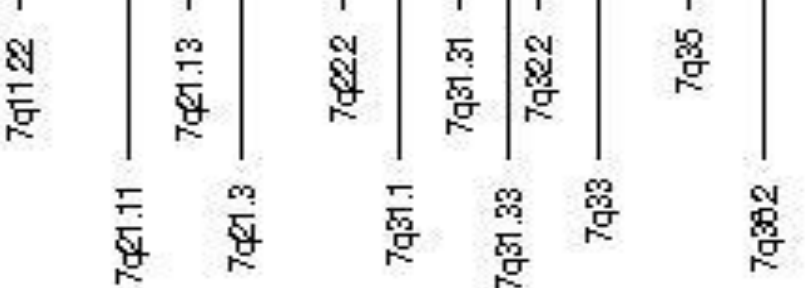

production in patients with essential hyper-tension is diminished under basal conditions, as established by measurement of urinary and plasma nitrate ${ }^{(21)}$. In addition, the offspring of hypertensive patients exhibit a reduced response to acetylcholine linked to a defect in the NO pathway ${ }^{(22)}$. These results strongly implicate genetic alterations in the eNOS gene in the pathogenesis of human essential hypertension. Recently identified another variant of the eNOS gene within exon 7: $\mathrm{G}$ to $\mathrm{T}$ conversion at nucleotide position 894 of eNOS cDNA resulting in a replacement of glutamic acid by aspartic acid at codon 298 (Glu298Asp). This variant was associated with both coronary spastic angina and myocardial infarction. ${ }^{(23,24)}$ 


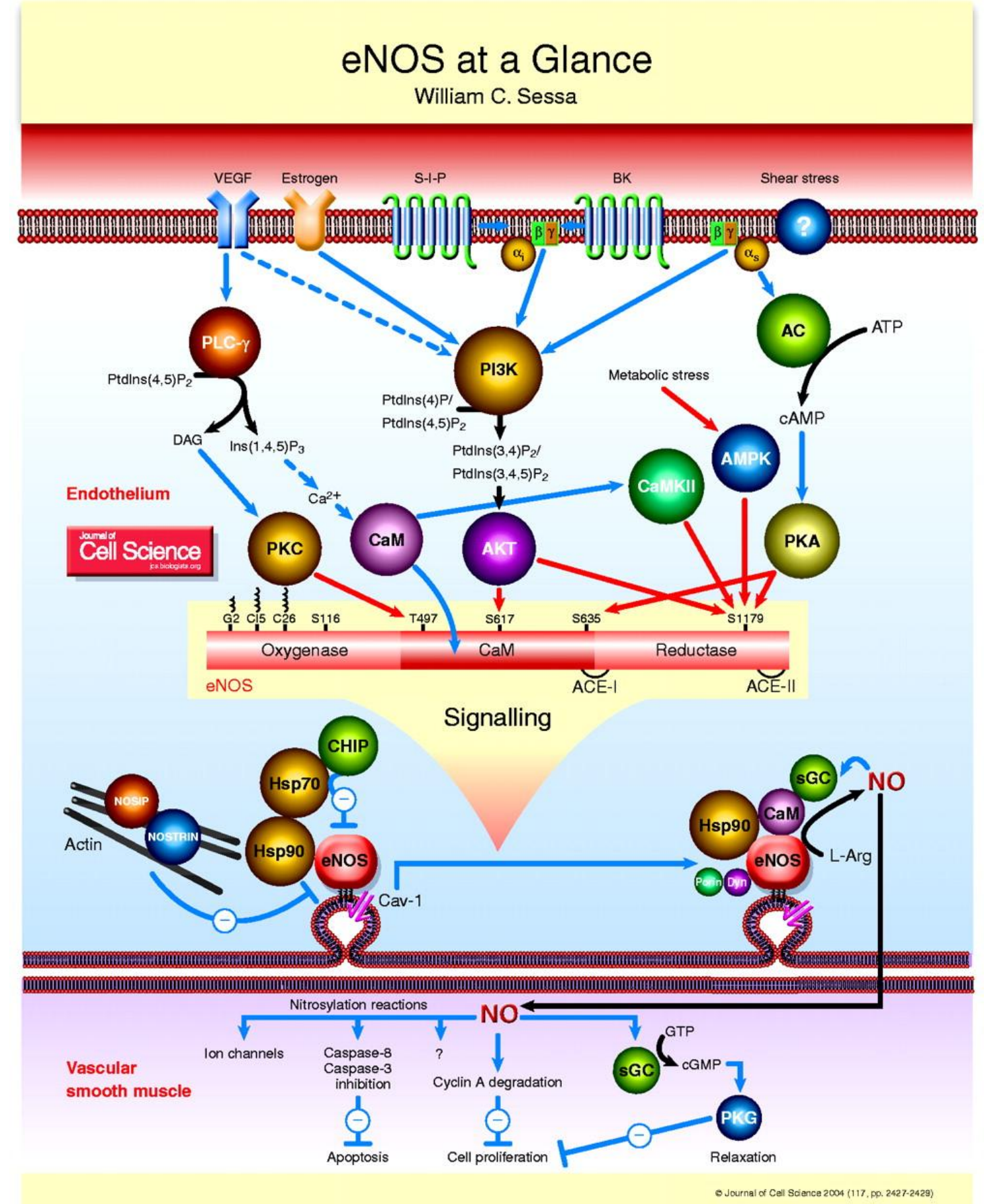

Figure 1: SOURCE- taken from Journal of Cell Science (2004- 117, pp2427-2429). - to depict the role of eNOS in Vascular Smooth Muscle. (Courtesy- William C. Sessa)

To further elucidate the genetic involvement of the eNOS gene in essential hypertension, we examined the possible association between the Glu298Asp variant and essential hypertension in South Indian population. The aim of this study was to select patients based on Unani Principles of medicine and genotyping them for polymorphism of eNOS gene.

\section{Materials and Methods}

\section{Selection of Study Subjects}

This study was approved by the Institutional Ethics Committee of CRIUM, following the principles of Helsenki Declaration for patient consent. A total of 100 patients of Essential Hypertension were selected on the basis of clinical history by Unani physicians from the OPD clinic of Central Research Institute of Unani Medicine (CRIUM, Hyderabad). The clinical features, their family history and other triggering factors were noted in the CRF proforma as followed by the Unani system of medicine. A control group

\section{Volume 5 Issue 3, March 2016}




\section{International Journal of Science and Research (IJSR) \\ ISSN (Online): 2319-7064 \\ Index Copernicus Value (2013): 6.14 | Impact Factor (2014): 5.611}

of individuals were selected who were free of a positive family history of essential hypertension and other chronic diseases. Mean age for patients and controls were almost similar. 100 healthy volunteers served as the controls; they were also systematically examined by Unani physicians at CRIUM. As per the Unani concept the disease hypertension is the resultant effect of excess of "dam" (pulse-rate) in the blood and the patients with a temperament of damvi (sanguine) were identified by the clinical phenotyping criteria as described in Unani classical texts. Healthy volunteers were also identified by the clinical phenotyping criteria and they also belonged to the sanguine temperament as in the case of patients.

A specially designed case record form as per the Unani classical text was designed for assessment of humours and the information obtained were recorded from healthy volunteers as well as patients. The subjects and patients have also filled in the willingness form to take part in the research process. The CRFes were then analysed for their dominant clinical phenotype or temperament based on the Unani classics.

The dominant clinical phenotype or the temperament obtained in these patients and healthy volunteers had the dominance of the humour-,Dam ${ }^{\text {ee }}$ which was obtained by a scoring pattern based on clinical phenotyping assessment. After assessment of the dominant clinical phenotype they were further subjected to blood sample collection, genomic DNA isolation, identification and genetic profiling of relevant gene by PCR in relation to the disease Hypertension and also the dominant clinical phenotype.

\section{Blood Sample Collection}

Two $\mathrm{ml}$ of whole blood was collected by veni puncture from all the 200 cases (100 Hypertensive and 100 controls). Blood was collected in sterile syringes and was transferred to K2 EDTA vacutainers. The collected samples were transported in an ice box to the molecular biology laboratory. The blood samples were stored at $-4^{\circ} \mathrm{C}$ in refrigerator till further use. Blood were drawn after approval by the Institute's ethical committee and after the sanction of the project by the Scientific Advisory committee. Informed consent was taken from the patients prior to collection of blood samples.

\section{Biochemical parameters of the study subjects}

Plasma glucose levels (fasting and postprandial), total cholesterol, TGs, HDL-C, LDL-C, VLDL-C, liver function tests (Bilirubin, SGPT, SGOT and ALP and renal function tests (Urea, creatinine)) were also analyzed by using an Erba Auto Analyser. Results have been presented in Table 1.

\section{Genetic analysis}

For genetic analyses, genomic DNA was isolated from peripheral blood samples by using HiPurA ${ }^{\mathrm{TM}}$ blood genomic DNA Purification Kit a column based DNA isolation kit, to get high yield. The DNA was then dissolved in Elution buffer, quality and quantity was checked by agarose gel electrophoresis and nanodrop reading by using Multimode reader. DNA was then stored at $-20^{\circ} \mathrm{C}$ until further use.
PCR amplification and genotype determination of eNOS $(894 G>T)$

The PCR amplification of eNOS $894 \mathrm{G}>\mathrm{T}$ was performed using the following primer sequence forward:51CATGAGGCTCAGCCCCAGAAC-312andreverse:51-

AGTCAATCCCTTTGGTGCTCAC-3를 as described by ${ }^{[18]}$ yielding a fragment of $206 \mathrm{bp}$. The PCR was performed with following PCR mix: each reaction was performed in a total volume of $50 \mu \mathrm{l}$ containing $10 \mathrm{mmol} / \mathrm{L}$ Tris $\mathrm{HCl}$ (PH 8.8), 50 $\mathrm{mmol} / \mathrm{L} \mathrm{KCl}, 1.5 \mathrm{mmol} / \mathrm{L} \mathrm{MgCl} 2,0.2 \mathrm{mmol}$ of each dNTP, 50 pmol of each of the two primers, 1 unit of Taq DNA polymerase, 100 ng of genomic DNA was added last to PCR. Reactions for eNOS 894G>T gene were carried out in a thermal cycler (Fermentas Life Sciences, Bangalore, India) consistent with the following scheme: $95^{\circ} \mathrm{C}$ for $2 \mathrm{~min}, 35$ cycles at 95 for $1 \mathrm{~min}, 60^{\circ} \mathrm{C}$ for $1 \mathrm{~min}, 72^{\circ} \mathrm{C}$ for $1 \mathrm{~min}$ and $72^{\circ} \mathrm{C}$ for 5 min. PCR products were visualized on $3 \%$ agarose gel stained with ethidium bromide before digestion to identify the gene fragments of interest. Similar conditions were used for eNOS. Further RFLP was performed using $\mathrm{Mbol}$ restriction enzyme (Bangalore Genei, India), Samples were incubated overnight at $37^{\circ} \mathrm{C}$ and the PCR products were separated on $3 \%$ agarose gel electrophoresis.

\section{Statistical Analysis}

All the above experiments were performed in triplicates. The observed genotype frequencies for eNOS (894G>T) polymorphism among Essential hypertensive patients and controls were tested for Hardy-Weinberg equilibrium using the $\mathrm{x} 2$ method. Values were expressed as percentage, mean, and standard deviation. The correlation values between Biochemical clinical data such as Sex, Glucose level and Lipid profile with the eNOS (894G>T) polymorphism were calculated for patients with different genotypes and have been expressed as mean \pm standard deviations. Fisher's two tailed test and Pearson correlation were used to evaluate statistical significance and calculate p value of the measured parameters and SPSS for Windows (version 11.0) software was used. 


\section{International Journal of Science and Research (IJSR) \\ ISSN (Online): 2319-7064 \\ Index Copernicus Value (2013): 6.14 | Impact Factor (2014): 5.611}

Table 1: Showing various parameters of Essential hypertension patients and control subjects

\begin{tabular}{|c|c|c|c|c|}
\hline Parameters & \begin{tabular}{|l|}
$\begin{array}{l}\text { Reference } \\
\text { values }\end{array}$ \\
\end{tabular} & Controls & $\begin{array}{l}\text { Hypertension } \\
\text { patients }\end{array}$ & \begin{tabular}{|l|}
$P$ \\
Value \\
\end{tabular} \\
\hline \multicolumn{5}{|l|}{ 1.Gender } \\
\hline Male & & 53 & 59 & \\
\hline Female & & 47 & 41 & \\
\hline 2.BMI & & $26.53 \pm 4.6$ & $28.34 \pm 5.3$ & \\
\hline \multicolumn{5}{|l|}{ 3.Glucose level } \\
\hline \begin{tabular}{|l}
$\begin{array}{l}\text { Fastingplasma } \\
\text { glucose (mg/dL) }\end{array}$ \\
\end{tabular} & $65-110$ & $94.9 \pm 18.6$ & $110.4 \pm 36$ & 0.000 \\
\hline $\begin{array}{l}\text { Postprandial } \\
\text { plasmaglucose } \\
(\mathrm{mg} / \mathrm{dL})\end{array}$ & $90-130$ & $136 \pm 45.14$ & $157 \pm 65.3$ & 0.026 \\
\hline \multicolumn{5}{|l|}{ 4.Lipid profile } \\
\hline $\begin{array}{l}\text { Triglyceride } \\
\text { (mg/dL) }\end{array}$ & $40-165$ & $135 \pm 46.8$ & $148 \pm 55.5$ & 0.082 \\
\hline Total Cholesterol & & $183 \pm 33.1$ & $198 \pm 49.4$ & 0.014 \\
\hline \begin{tabular}{|l|}
$\begin{array}{l}\text { HDL-Cholesterol } \\
(\mathrm{mg} / \mathrm{dL})\end{array}$ \\
\end{tabular} & $<40$ & $41 \pm 6.2$ & $42 \pm 5.5$ & 0.399 \\
\hline $\begin{array}{l}\text { LDL-Cholesterol } \\
(\mathrm{mg} / \mathrm{dL})\end{array}$ & $<120$ & $116 \pm 10.82$ & $127 \pm 12.36$ & \\
\hline \multicolumn{5}{|l|}{$\begin{array}{|ll|}\begin{array}{l}\text { 5.Liver function } \\
\text { tests }\end{array} \\
\end{array}$} \\
\hline SGPT (IU/L) & $10-40$ & $24.9 \pm 12.5$ & $22.1 \pm 12$ & 0.128 \\
\hline SGOT (IU/L) & $10-42$ & $23.8 \pm 9.7$ & $22.8 \pm 9.8$ & 0.509 \\
\hline Bilirubin (mg/dL) & $0.2-1.2$ & $0.72 \pm 0.32$ & $0.77 \pm 0.46$ & 0.026 \\
\hline ALP (IU/L) & $30-111$ & $87.8 \pm 75.9$ & $79.8 \pm 29.4$ & 0.336 \\
\hline Urea (mg/dL) & $13-45$ & $23.9 \pm 5.7$ & $28.4 \pm 8.5$ & 0.000 \\
\hline Creatinine (mg/dL) & $0.6-1.4$ & $1.07 \pm 1.1$ & $1.06 \pm 0.2$ & 0.945 \\
\hline
\end{tabular}

Data is presented as mean $\pm \mathrm{SD}$

$B M I$ body mass index, HDL high density lipoprotein, LDL low density lipoproteins.

\section{Results}

In this paper, we present the results of 100 Essential Hypertension patients along with 100 healthy volunteers which served as controls using the Unani criteria for patient selection.. The clinical profiles and demographic parameters of all the patients were compared with normal healthy controls. These parameters are presented in Figures. 1, \& 2. The clinical characteristics of the patients and the details of the demographic and Biochemical characteristic of the Essential hypertension patients and control are presented in Table 1.

It is seen that most patients were above 50 years of age with the glucose levels above $150 \mathrm{mg} / \mathrm{dL}$. (Figs.1,2). Further statistical analysis shows that the hypertension patients had higher values of not only glucose levels but also a high value of Triglycerides and cholesterol (Table 1, Fig 3\&4).Statistical analysis also further reveals that the liver function and renal function of both hypertensive and control samples were within the physiological range.

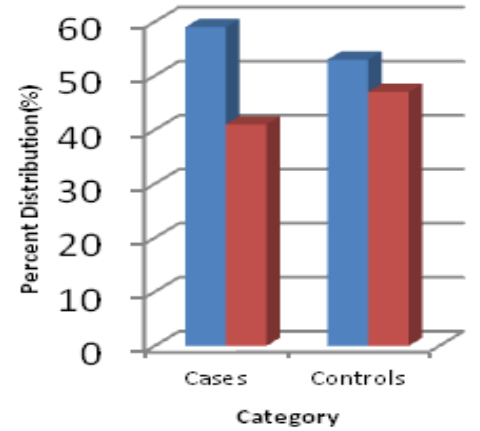

nale (\%)

- Female (\%)

Category

Figure 1: Showing sex distribution among HTN Patients and controls

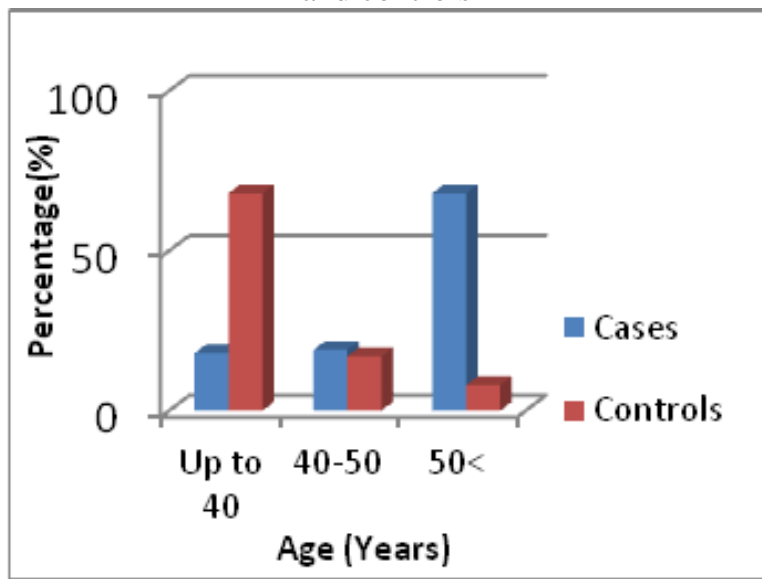

Figure 2: Showing age distribution among HTN Patients and controls

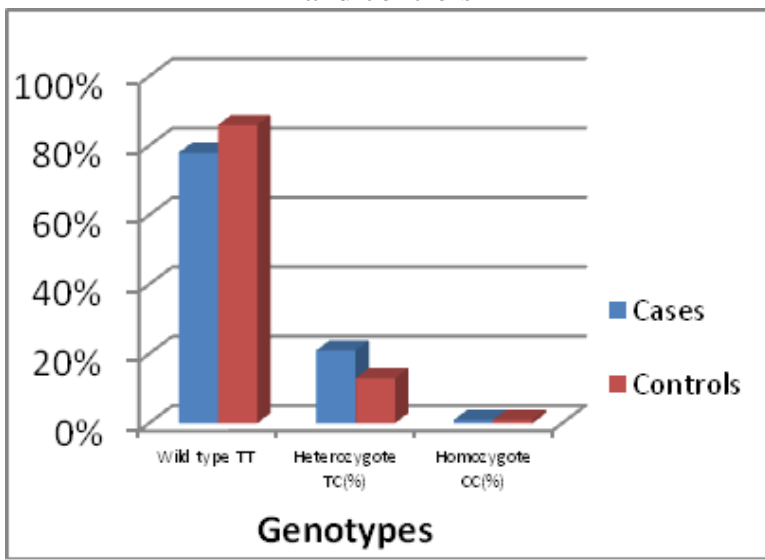

Figure 3: Showing Genotype distribution among HTN Patients and controls

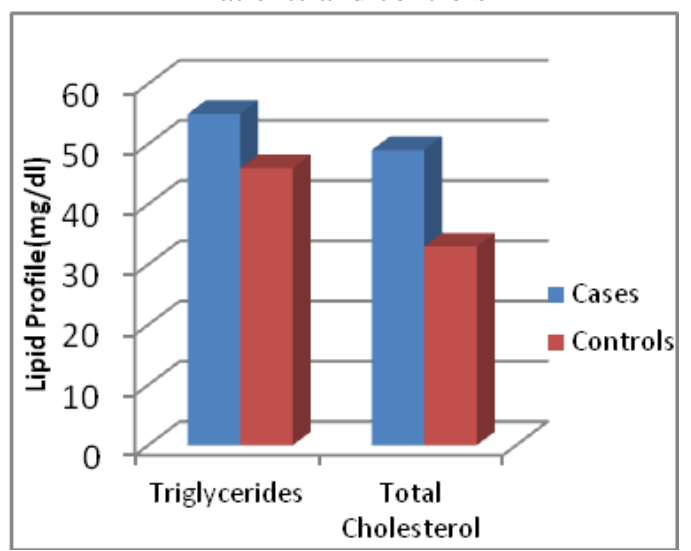

Figure 4: Showing the lipid profile (triglycerides,total cholesterol) among HTN Patients and controls 


\section{International Journal of Science and Research (IJSR) \\ ISSN (Online): 2319-7064 \\ Index Copernicus Value (2013): 6.14 | Impact Factor (2014): 5.611}

DNA extraction for Genotyping by PCR and RFLP

We isolated genomic DNA and amplified the gene of interest eNOS by PCR. Mutational analysis of the gene by RFLP was carried out to confirm the presence of desired PCR fragment 206 bp of eNOS. The eNOS PCR product was digested with $\mathrm{Mbol}$ restriction enzyme. The PCR-RFLP results were checked on $3 \%$ Agarose gel and the band patterns were analyzed.

Genotype determination of eNOS gene polymorphism in 100 Essential Hypertension patients and 100 healthy controls

The eNOS 894G>T (Glu298/Asp) variant was detected by polymerase chain reaction and Restriction fragment length polymorphism analysis (RFLP) in 100 Essential Hypertension patients and 100 healthy controls. The genotypic frequencies of eNOS $894 \mathrm{G}>\mathrm{T}$ gene of 100 patients with Essential Hypertension and for healthy control subjects were GG 78 (78\%), GT 21 (21\%),TT 01(01\%), and 86(86\%) GT 13 (13\%),TT 01(01 \%) respectively. We observed that the GG genotype of wild type shows less frequency in cases compared to controls (78 vs 86 \%) respectively. Similarly, the GT genotype was also present in (21vs13\%), respectively (Table 2) Next we looked at the genotype frequency under Hardy-Weinberg equilibrium, we found a significant distribution of genotypes in the control group did differ significantly from that expected to be under Hardy-Weinberg equilibrium, and was a significant deviation from Hardy-Weinberg in the case group, with an less frequency of GG homozygotes among the patients with essential hypertension. The genotype (TT) homozygous in both essential hypertension patients and controls were present in $01 \%$ only. This may be an interesting finding and a confirmatory approach is required with more number of samples.

Table 2: Genotype frequency of the eNOS gene G894T in patients and control group

\begin{tabular}{|l|c|c|c|}
\hline $\begin{array}{c}\text { Study group } \\
n=200\end{array}$ & $\begin{array}{c}\text { Wild type } \\
\text { GG(\%) }\end{array}$ & $\begin{array}{c}\text { Heterozygous } \\
\text { GT }(\%)\end{array}$ & $\begin{array}{c}\text { Homozygous } \\
\text { TT }(\%)\end{array}$ \\
\hline Cases $(\mathrm{n}=100)$ & $78(78 \%)$ & $21(21 \%)$ & $01(1 \%)$ \\
\hline Controls $(\mathrm{n}=100)$ & $86(86 \%)$ & $13(13 \%)$ & $01(1 \%)$ \\
\hline
\end{tabular}

\section{Discussion}

Globally hypertension is a disease which occurs silently and can cause morbidity and mortality. The practicing Unani physicians in their attempts to safeguard the humans from this disease are now starting to understand that medication could be derived if the root cause of this disease is understood at the cell or molecular level. Hence in an attempt to look at this disease at a molecular level we present the results of 100 hypertensive cases as compared to 100 non-HT volunteers of Damvi temperament selected by the Unani physicians of CRIUM. We determined their demographic, epidemiological and biochemical parameters, before starting the genetic studies for which we selected the vascular endothelial modulator gene- the eNOS gene for this study. In this, we found some novelty in presenting this data. Such an attempt has never been done before; in fact this is the first report of HT patients from a Unani point of view. What is new here is the discovery of the "mijaz" (temperament) of the HT patients and their genotype distribution. Our results showed more number of males in both cases and controls, and the age at which this disease strikes was found to be $>50$ years. The biochemical parameters as expected were higher in cases than controls (table-1). At the genetic level- the results of eNOS genotyping results were mostly similar to the findings of other studies ${ }^{(25,26)}$.

As Nitric oxide (NO) is an important cellular signaling molecule involved in many physiological and pathological processes we found it important to get started of analyzing the role of this gene. It is a powerful vasodilator with a short half-life of a few seconds in the blood ${ }^{(14,15)}$. eNOS gene encoding eNOS is located on chromosome 7q35-36 and it causes increased oxidative stress due to free radical generation and plays an important role in the pathogenesis of microvascular complications in humans ${ }^{[16]}$. Production of eNOS has been reported to be either increased or decreased in the presence of high glucose concentrations ${ }^{[17]}$. eNOS is short lived, highly reactive intercellular signaling molecule. In addition to its inter-cellular signaling activities, eNOS plays a major role in the regulation of vascular tone, including retinal circulation and vascular remodeling. High levels of NO may react with superoxide anion to generate peroxynitrite radical, which binds to proteins and thus affects their function. In eNOS gene several variants have been described such as a variable number of tandem repeats in the intron 4, a cytosine-adenine (CA) repeat, microsatellite marker in the intron 13 have been described. Additionally, SNPs have also been reported in the promoter region of the eNOS gene at $\mathrm{G}$ to $\mathrm{T}$ transversion position at 894 in exon 7 (894G>T), which results in the incorporation of aspartate in place of glutamate (Glu298Asp). The eNOS 894G>T (Glu298Asp) gene are widely studied and found to be associated with low plasma NO concentrations and reduced vascular reactivity, emphasizing their importance in the onset of cardiovascular diseases and atherosclerosis $(18,25,26)$

\section{Conclusion}

This is the first report based on the epidemiology of the Damvi (Sanguine) patients who were identified following Unani-principles and these were genotyped for eNOS gene, and are being presented to the unani physicians for treatment.

\section{Conflict of Interest}

None

\section{Acknowledgements}

We are grateful to CCRUM and BMMRC for their encouragement and help.

\section{References}

[1] Leslie Charles-Asian Medical Systems-a comparative study. Eds (Charles Leslie) University of California Press, London, 1976. 


\section{International Journal of Science and Research (IJSR) \\ ISSN (Online): 2319-7064 \\ Index Copernicus Value (2013): 6.14 | Impact Factor (2014): 5.611}

[2] Dunn L. Frederick: Traditional Asian Medicine and Cosmopolitan Medicine as Adaptive Systems-In: Asian medical Systems-a comparative study. Eds (Charles Leslie) University of California Press, London 1976.

[3] Azmi-Ahmad Altaf: Basic concepts of Unani medicine a-critical study.

[4] Hameed Abdul H.K. "Atemperament \& Medicine" International Congress of Orientalists, Paris, 1973.

[5] Nafis Burhan-al-din, Kulyat-e-Nafisi Vol.2, Daftar-alMasihi, Delhi, 1935.

[6] Abu Ali Sina, Al Khanoon-fit-Tibb, Daftar-al-Masihi, Delhi, 1930.

[7] Hameed Abdul and Vohra, S.B. Is Human Body A Microcosm Paper presented at international Conference, New Delhi, 1987.

[8] Kargar, S. and Siegel, R.E. Galenses System of Philosophy and Medicine, Vol I \& II, 1968

[9] Taiyeb, M.; Philosophy of Graeco-Arabian Medicine, AMU Press, 1983.

[10] Unani system of medicine - The science of health and healing. Department of AYUSH;Ministry of Health \& Family Welfare; Government of India - New Delhi 2013.

[11] Nathan C, Xie QW. Nitric oxide synthases: Roles, tolls and controls. Cell 1994;78:95-118.

[12] Williams RR, Hunt SC, Hasstedt SJ, Hopkins PN, Wu LL, Berry TD, Stults BM, Barlow GK, Schumacher MC, Lifton RP, Lalouel JM. Are there interactions and relations between genetic and environmental factors predisposing to high blood pressure? Hypertension. 1991; 18(suppl I):I-29-I-37.

[13] Ross R. Atherosclerosis-an inflammatory disease. N Engl J Med 1999;340:115-26.

[14] Sheng H, Ignarro LJ (1996) Biochemical and immune histochemical characterization of nitric oxide synthase in the rat retina. Pharmacol Res 33:29-34

[15] Forte P, Copland M, Smith LM, Milne E, Sutherland J, Benjamin N.Basal nitric oxide synthesis in essential hypertension. Lancet. 1997; 349:837-842.

[16] Taddei S, Virdis A, Mattei P, Ghiadoni L, Sudano I, Salvetti A. Defective L -arginine/nitric oxide pathway in offspring of essential hypertensionpatients. Circulation. 1996;94:1298-1303

[17] Bonnardeaux A, Nandaud S, Charru A, Jeunemaitre X, Corvol P,Soubrier F. Lack of evidence for linkage of the endothelial cell nitricoxide synthase gene to essential hypertension. Circulation. 1995;91:96-102.

[18] Ross R. Atherosclerosis-an inflammatory disease. N Engl J Med 1999;340:115-26.

[19] Vallance P, Collier J, Moncada S. Effects of endothelium-derived nitric oxide on peripheral arteriolar tone in man. Lancet. 1989;2:997-1000.

[20]Huang PL, Huang Z, Mashimo H, Bloch KD, Moskowitz MA, Bevan JA,

[21] Fishman MC. Hypertension in mice lacking the gene for endothelial nitric oxide synthase. Nature. 1995; 377:239-242.

[22] Forte P, Copland M, Smith LM, Milne E, Sutherland J, Benjamin N.Basal nitric oxide synthesis in essential hypertension. Lancet. 1997; 349:837-842.

[23] Taddei S, Virdis A, Mattei P, Ghiadoni L, Sudano I, Salvetti A. Defective L -arginine/nitric oxide pathway in offspring of essential hypertensionpatients Circulation. 1996; 94:1298-1303.

[24] Bonnardeaux A, Nandaud S, Charru A, Jeunemaitre X, Corvol P,Soubrier F. Lack of evidence for linkage of the endothelial cell nitricoxide synthase gene to essential hypertension. Circulation. 1995;91:96-102.

[25] Fulton, D., Gratton, J. P. and Sessa, W. C. (2001). Posttranslational control of endothelial nitric oxide synthase: why isn't calcium/calmodulin enough? J. Pharmacol. Exp. Ther. 299, 818-24.

[26] Rabbani Syed, Moin Uddin Biyabani, Shiva Prasad, Farha Deeba and Kaiser Jamil, Evidence of association of a common variant of the endothelial nitric oxide synthase gene $\left(\mathrm{Glu}^{298} \rightarrow\right.$ Asp polymorphism) to coronary artery disease in South Indian population. Journal of Medical Genetics and Genomics, 2011, 3 (1): 13-18.

[27] Rabbani Syed and Kiaser Jamil: Role of VNTR of eNOS gene polymorphism in CAD in South Indian Population. Soudi Biological Society Journal; 2010; Volume 17 ,No 3 Science Direct July 2010) doi:10.1016/j.sjbs.2010.04.003 